\title{
Novel RNA Modifications in the Nervous System: Form and Function
}

\author{
John S. Satterlee, ${ }^{1}$ @Maria Basanta-Sanchez, ${ }^{2}$ SSandra Blanco, ${ }^{3}$ Jin Billy Li, ${ }^{4}$ Kate Meyer, ${ }^{5}$ Jonathan Pollock, ${ }^{1}$ \\ Ghazaleh Sadri-Vakili, ${ }^{6}$ and Agnieszka Rybak-Wolf ${ }^{7}$ \\ ${ }^{1}$ National Institute on Drug Abuse, Bethesda, Maryland 20892, ${ }^{2}$ RNA Institute, State University at Albany, Albany, New York 12222, ${ }^{3}$ Wellcome Trust, \\ Medical Research Council Stem Cell Institute, University of Cambridge, Tennis Court Road, Cambridge CB2 1QR, United Kingdom, ${ }^{4}$ Stanford University, \\ Department of Genetics, Stanford, California 94305, ${ }^{5}$ Department of Pharmacology, Weill Medical College, Cornell University, New York, New York 10065, \\ ${ }^{6}$ MassGeneral Institute for Neurodegenerative Disease, Massachusetts General Hospital, Boston, Massachusetts 02129-4404, and ${ }^{7}$ Max-Delbrück-Centrum \\ für Molekulare Medizin, 13092 Berlin, Germany
}

Modified RNA molecules have recently been shown to regulate nervous system functions. This mini-review and associated minisymposium provide an overview of the types and known functions of novel modified RNAs in the nervous system, including covalently modified RNAs, edited RNAs, and circular RNAs. We discuss basic molecular mechanisms involving RNA modifications as well as the impact of modified RNAs and their regulation on neuronal processes and disorders, including neural fate specification, intellectual disability, neurodegeneration, dopamine neuron function, and substance use disorders.

\section{Introduction}

Chemical modifications play a crucial role in the regulation of biological processes. For example, the function of a protein is often modulated by its stable tagging with different chemical groups (phosphates, sugars, or lipids), whereas specific chemical marks made along the chromatin (the DNA and/or its packaging proteins) can influence gene expression. A variety of posttranscriptional modifications of RNA are also found in all organisms. The RNA Modification Database indicates that there are at least 65 RNA modifications that arise in eukaryotic cells (Cantara et al., 2011). Historically, transfer RNA (tRNA) and ribosomal RNA (rRNA) have been shown to be heavily modified, but some of these modifications also occur in messenger RNA (mRNA) (Meyer et al., 2012; Li and Church, 2013; Russell and Limbach, 2013; Wang et al., 2014c). Most recently, RNA modifications have also been found in noncoding RNAs (ncRNAs) (Storz, 2002; Matera et al., 2007; Yu and Chen, 2010; Meyer et al., 2012; Squires et al., 2012).

A few covalent RNA modifications, such as 5' mRNA capping, alternative splicing, and polyadenylation, have been studied extensively. To date, however, most RNA modifications have not been well characterized for two major technical reasons. The first reason is that many modified RNA bases are recognized by reverse transcriptases the same way as their unmodified counterparts. Because a common step in many RNA experiments is to

Received Aug. 5, 2014; revised Sept. 13, 2014; accepted Sept. 17, 2014.

We thank the SFN program committee for selecting this mini-symposium topic and Dena Procaccini for excellent assistance in preparing the manuscript. The views expressed in this article are solely those of the authors and may not necessarily reflect those of the National Institutes of Health.

The authors declare no competing financial interests.

Correspondence should be addressed to Dr. John S. Satterlee, National Institute on Drug Abuse, 6001 Executive Blvd, Bethesda, MD 20892. E-mail: satterleej@nida.nih.gov.

DOI:10.1523/JNEUROSCI.3236-14.2014

Copyright $\odot 2014$ the authors $\quad 0270-6474 / 14 / 3415170-08 \$ 15.00 / 0$ reverse transcribe the RNA into cDNA, this effectively "erases" any information concerning the types and locations of RNA modifications that might have been present (Behm-Ansmant et al., 2011). A second reason is that our technical ability to detect and quantitate RNA modifications has been limited until recently (Yan et al., 2013; Kullolli et al., 2014). Both of these issues have severely impaired our ability to systematically characterize the "epitranscriptome," which can be defined as all of the chemical modifications of RNA molecules (both coding and noncoding) (Saletore et al., 2012; Hussain et al., 2013a; Li and Mason, 2014; Meyer and Jaffrey, 2014). Thus, the functional roles of many post-transcriptional RNA modifications remain unknown, although they could potentially influence parameters, such as RNA stability, translation, trafficking, localization, enzymatic or sensing activity, regulatory capabilities, or patterns of interactions with other molecules.

The purpose of this mini-review and the associated SFN minisymposium is to highlight the types and known functions of several novel modified RNAs in the nervous system. We will discuss the two most well-studied mammalian mRNA modifications, including N6-methyladenosine $\left(\mathrm{m}^{6} \mathrm{~A}\right)$ and 5-methylcytosine $\left(\mathrm{m}^{5} \mathrm{C}\right)$ as well as evolving technologies to identify and quantify other less well-characterized RNA modifications in mRNA and regulatory RNA. We will also discuss the role of adenosine to inosine-edited RNAs in brain function as well as the properties of a new topological class of RNA (circular RNA). The known and postulated functional roles of these modifications in neuronal processes and diseases including neural fate specification, dopamine neuron function, neurological disorders, intellectual disability, and substance use disorders, will be described.

$\mathrm{m}^{6} \mathrm{~A}$

$\mathrm{m}^{6} \mathrm{~A}$ is an RNA modification that was recently discovered to be a widespread feature of mammalian mRNAs (Dominissini et al., 
2012; Meyer et al., 2012). Although $\mathrm{m}^{6} \mathrm{~A}$ has been found in mRNAs from diverse tissue types, the brain is among the tissues with the highest levels of $\mathrm{m}^{6} \mathrm{~A}$. This finding, coupled with the fact that $\mathrm{m}^{6} \mathrm{~A}$ is known to be dynamically regulated (Dominissini et al., 2012; Schwartz et al., 2013), suggests that adenosine methylation could potentially mediate the intracellular response to neuronal signaling events by regulating the function of neuronal mRNAs. Additionally, recent studies have identified two members of the 2-oxoglutarate-dependent dioxigenase family of proteins as $\mathrm{m}^{6} \mathrm{~A}$ demethylases (Jia et al., 2011; Zheng et al., 2013). One of these, FTO, has been linked to a variety of human diseases, including cancer (Garcia-Closas et al., 2013; Iles et al., 2013), obesity (Tung and Yeo, 2011), attention-deficit/ hyperactivity disorder (Choudhry et al., 2013), and Alzheimer's disease (Keller et al., 2011; Reitz et al., 2012). Additionally, humans with a nonsynonymous mutation in the FTO enzymatic domain exhibit brain malformation and impaired brain function (Reitz et al., 2012), and intronic FTO single nucleotide polymorphisms have been associated with abnormal brain volumes in both adolescents (Melka et al., 2013) and healthy elderly subjects (Ho et al., 2010). These findings suggest that FTO-mediated $\mathrm{m}^{6} \mathrm{~A}$ demethylation might contribute to neuronal signaling pathways that regulate brain development and function.

FTO is highly expressed within the brain, and its expression level and subcellular localization within distinct brain regions are susceptible to dynamic regulation (Boender et al., 2012; Vujovic et al., 2013). Thus, targeted $\mathrm{m}^{6} \mathrm{~A}$ demethylation directed by FTO is a potential mRNA regulatory mechanism through which neurons might regulate their response to various signaling events. Indeed, recent studies have shown that FTO knock-out mice have an abnormal behavioral and electrophysiological response to cocaine (Hess et al., 2013). Targeted deletion of FTO in dopaminergic neurons revealed impaired presynaptic dopamine receptor signaling, suggesting that FTO is necessary for the proper presynaptic response to extracellular dopamine levels (Hess et al., 2013). Additionally, analysis of mRNA methylation in dopaminergic neurons following FTO loss of function identified a subset of mRNAs whose $\mathrm{m}^{6} \mathrm{~A}$ levels were influenced by FTO. Many of these transcripts encode proteins involved in the response to dopamine, suggesting that FTO-mediated dynamic methylation of neuronal mRNAs is necessary for proper dopaminergic signaling. Given the multitude of neuronal pathways that involve dopaminergic transmission, it is likely that fine-tuning of neuronal $\mathrm{m}^{6} \mathrm{~A}$ levels regulates a variety of pathways contributing to mental health and disease. Further research into the mechanisms through which $\mathrm{m}^{6} \mathrm{~A}$ regulates mRNAs in response to neuronal signaling events will likely reveal additional roles for this widespread modification in neuronal function.

$\mathrm{m}^{5} \mathrm{C}$

Although the existence of $\mathrm{m}^{5} \mathrm{C}$ in DNA and RNA was described over 5 decades ago, its precise regulatory functions in RNA remain unclear (Gold et al., 1963; Garcia-Closas et al., 2013). Recent advances in high-throughput techniques to globally map $\mathrm{m}^{5} \mathrm{C}$ in RNA and the association of mutations in genes encoding $\mathrm{m}^{5} \mathrm{C}$ methyltransferases with intellectual disability in humans have provided important insights into the function of this modification. Bisulfite sequencing was the first methodology adapted to globally detect $\mathrm{m}^{5} \mathrm{C}$ in RNA (Schaefer et al., 2009; Squires et al., 2012). The development of three more transcriptome-wide approaches followed (Hussain et al., 2013a). Using these highthroughput methods, $\mathrm{m}^{5} \mathrm{C}$ has been identified in coding as well as noncoding RNAs, such as vault RNAs (vRNAs) and tRNAs
(Motorin et al., 2010; Squires et al., 2012; Amort et al., 2013; Edelheit et al., 2013; Hussain et al., 2013a, b; Khoddami and Cairns, 2013). Functionally, $\mathrm{m}^{5} \mathrm{C}$ has been shown not only to affect degradation and stress-induced ribonuclease cleavage of tRNAs but also to change global protein translation (Alexandrov et al., 2006; Chow et al., 2007; Chernyakov et al., 2008; Schaefer et al., 2010; Chan et al., 2012; Tuorto et al., 2012; Metodiev et al., 2014). In addition, hypomethylation of vRNAs alters their processing into microRNA-like RNAs (Hussain et al., 2013b). In rRNA, $\mathrm{m}^{5} \mathrm{C}$ is also thought to play a role in translation (Chow et al., 2007; Metodiev et al., 2014). $\mathrm{m}^{5} \mathrm{C}$ modification has been proposed to affect mRNA stability; however, its function is still controversial (Zhang et al., 2012; Hussain et al., 2013a).

The two best described $\mathrm{m}^{5} \mathrm{C}$ RNA methyltransferases in higher eukaryotes are DNMT2 and NSUN2 (Brzezicha et al., 2006; Frye and Watt, 2006; Goll et al., 2006). Although no gross phenotype has been observed in DNMT2-deficient mice or plants (Goll et al., 2006; Tuorto et al., 2012), DNMT2 loss-offunction mutant flies show increased sensitivity to oxidative stress, and DNMT2 loss in zebrafish affects liver, retina, and brain development (Rai et al., 2007; Schaefer et al., 2010). Studies performed in NSUN2-deficient mice, flies, and cell lines, suggest roles for $\mathrm{m}^{5} \mathrm{C}$ RNA modification in cellular signaling, stem cell biology, tissue development, differentiation, and cancer (Frye and Watt, 2006; Sakita-Suto et al., 2007; Hussain et al., 2009; Frye et al., 2010; Blanco et al., 2011; Abbasi-Moheb et al., 2012; Tuorto et al., 2012; Hussain et al., 2013c). NSUN2 is highly expressed during mouse embryogenesis and is specifically enriched in the brain (Blanco et al., 2011). Most remarkably, human whole exome sequencing studies recently have correlated NSUN2 gene mutations with a syndromic form of autosomal-recessive intellectual disability, as well as a Dubowitz-like syndrome, and a Noonan-like syndrome (Abbasi-Moheb et al., 2012; Khan et al., 2012; Martinez et al., 2012; Fahiminiya et al., 2014). Dubowitzlike syndrome includes an intellectual disability phenotype as well as microcephaly, and facial dysmorphism, whereas individuals affected by Noonan-like syndrome present developmental delay as well as facial dysmorphism. The described substitutions result in truncation and degradation of NSUN2 transcript leading to complete loss or mislocalization of NSUN2 protein into the cytosol. Similar to patients, NSUN2 knock-out mice are smaller than their littermates and have microcephaly and behavioral and memory deficits (Blanco et al., 2014).

Together, these data suggest that NSUN2-mediated RNA methylation plays an essential role in brain development. But how loss of this methylation causes the disease symptoms described above is not yet fully understood. Loss of tRNA methylation could be the main defect leading to these complex intellectual disorders because the vast majority of NSUN2 targets are tRNAs (Squires et al., 2012; Hussain et al., 2013b; Khoddami and Cairns, 2013). It is known that loss of DNMT2-mediated $\mathrm{m}^{5} \mathrm{C}$ methylation increases tRNA stress-induced cleavage in flies, and cleavage of tRNAs and repression of protein translation is a conserved response to several stress stimuli in eukaryotes (Thompson et al., 2008; Fu et al., 2009; Yamasaki et al., 2009; Emara et al., 2010; Schaefer et al., 2010; Spriggs et al., 2010; Ivanov et al., 2011; Gebetsberger et al., 2012; Sobala and Hutvagner, 2013). Furthermore, neurodevelopmental disorders are commonly associated with oxidative stress (De Felice et al., 2012; Lintas et al., 2012) and increased tRNA cleavage has been recently directly linked to neurodevelopmental and neurodegenerative conditions (Karaca et al., 2014; Schaffer et al., 2014). Additionally, in recent studies performed by Sandra Blanco and colleagues 
in Dr. Michaela Frye's laboratory, loss of NSUN2-mediated tRNA methylation-induced angiogenin-mediated tRNA cleavage and led to accumulation of 5' tRNA fragments. These tRNA fragments activate stress response pathways leading to reduced rates of protein translation, decreased cell size, decreased synaptogenesis, and increased cell death. These phenotypes can be rescued by inhibition of angiogenin and stress pathways during mouse embryogenesis (Blanco et al., 2014). This study shows the first association between $\mathrm{m}^{5} \mathrm{C}$ regulation during cellular stress responses and noncanonical functions of tRNAs in neurodevelopment and in human diseases.

\section{Identifying novel RNA modifications in the nervous system}

We have just described the known functions of two of the most well-characterized mammalian RNA modifications; however, many others exist and some have recently been found in ncRNAs (Storz, 2002; Matera et al., 2007; Yu and Chen, 2010; Squires et al., 2012). Current technologies, such as immunoprecipitation followed by RNA-sequencing, have allowed us to monitor a select number of modifications, including $\mathrm{m}^{5} \mathrm{C}, \mathrm{m}^{6} \mathrm{~A}$, and inosine (I). This advance has enabled researchers to test whether specific RNA modifications are associated with genes related to brain function and the development of neurological disorders (Meyer et al., 2012; Squires et al., 2012; Li and Church, 2013). However, many of these post-transcriptional modifications are not present on RNA at high levels and consequently little is known about the extent to which they are found in individual RNAs, classes of RNAs (e.g., ncRNAs or mRNAs), or cell types. Thus, highly sensitive and accurate technologies are needed to monitor and quantify RNA modifications that occur in low abundance RNA species, such as certain mRNAs, snoRNAs, miRNAs, siRNAs, and lncRNAs. Mass spectrometry (MS) in combination with high resolution separations, such as ultra-high performance liquid chromatography, can provide these sensitive, accurate, and robust measurements.

ncRNAs are highly expressed in the brain and play an essential role in neural functions, brain development, and evolution (Satterlee et al., 2007; Im and Kenny, 2012; Qureshi and Mehler, 2012; Ng et al., 2013; Petri et al., 2014; Roberts et al., 2014). Recently, robust methods have been developed to produce medial frontal cortex cells from human pluripotent stem cells in a highly efficient and reproducible manner (van de Leemput et al., 2014). This system enables the monitoring of modifications of ncRNAs and mRNAs during the different stages of brain development that may be important for differentiation. The chemical composition and physical properties of the modified nucleosides allow for individual characterization using chromatography in combination with collision-induced fragmentation and tandem MS (Quinn et al., 2013; Su et al., 2014). Ultra-high performance liquid chromatography-MS analysis of total RNA extracted from medial frontal cortex cells reveals low femtomole to attomole levels of 33 of 112 currently known RNA modifications (unpublished data). Increases in the levels of certain modifications, such as $\mathrm{m}^{5} \mathrm{C}, \mathrm{m}^{7} \mathrm{G}, \mathrm{m}^{1} \mathrm{~A}$, and $\mathrm{m}^{6} \mathrm{~A}$, are highly indicative of the level of transcription during cortical differentiation. Less common modifications, not as directly related to transcription (e.g., 2-thiocytidine $\left(s^{2} \mathrm{C}\right)$ and $\left.\mathrm{I}\right)$, were also found to increase during cortical differentiation, whereas pseudouridine $(\Psi)$ and $2^{\prime}-\mathrm{O}-$ methylcytidine $(\mathrm{Cm})$ remained fairly constant. Ongoing efforts are focused on the separation of individual RNAs types, such ncRNAs and mRNAs, to investigate the level of modifications more accurately. Complementary RNA-seq data will be used to determine the existence of the corresponding modifying enzymes and to work towards understanding the biological pathways involved. Ultimately, these new methods will yield insights into which RNA modifications are present in brain ncRNAs and mRNAs and how they change during cortical differentiation. These studies will be the first step toward better understanding the functions of messenger and regulatory RNAs and their modifications in human brain disorders.

\section{A-to-I RNA editing in the nervous system}

Adenosine-to-inosine (A-to-I) editing is a cotranscriptional phenomenon that occurs at the pre-mRNA level. It is catalyzed by adenosine deaminases acting on RNA (ADARs), which bind double-stranded RNA and deaminate adenosine to form inosine, which is recognized as guanosine during translation (Nishikura, 2010; Rosenthal and Seeburg, 2012; Li and Church, 2013). Thus, RNA editing can contribute to the diversity of the transcriptome by changing the amino acid sequences of proteins, altering the locations of start or stop codons, influencing alternative splicing patterns, and affecting the ability of miRNAs to bind to their target sites (Rueter et al., 1999; Kawahara et al., 2007; Nishikura, 2010). Dysregulation of A-to-I RNA editing can lead to severe consequences. For example, ablation of editing in the glutamate receptor gene GluA2 Q/R site results in excess influx of calcium into neurons leading to postnatal death in mice (for further details, see below) (Brusa et al., 1995). Importantly, abnormal editing levels have been observed in a variety of diseases, such as depression and suicide, epilepsy, amyotrophic lateral sclerosis, and several cancers (Tariq and Jantsch, 2012; Slotkin and Nishikura, 2013).

Although previous work has shown that ADAR expression levels are generally higher in brain than other tissues, we lack comprehensive studies examining how RNA editing is spatiotemporally regulated in mammals. With the recent expansion of RNA editing sites in mouse and human, there is an immediate need to comprehensively characterize the extent of editing at individual sites in different biological contexts (Geiger et al., 1995; Melcher et al., 1996; Chen et al., 2000; Li et al., 2009; Bahn et al., 2012; Danecek et al., 2012; Peng et al., 2012; Ramaswami et al., 2012, 2013; Ramaswami and Li, 2014).

Transcriptome-wide profiling of A-to-I RNA editing in a large number of human and mouse samples has been performed using a recently developed targeted RNA sequencing method (Zhang et al., 2014) as well as publicly available data. Differences in RNA editing levels between tissue types, developmental stages, and species were observed, leading to findings that agree with previous, small-scale studies (Wahlstedt et al., 2009), as well as findings that are novel and unexpected. At an unprecedented scale, this study underscores the unexpected complexities of A-to-I RNA editing and paves the way for future studies aimed at understanding this important gene regulatory mechanism.

\section{A-to-I RNA editing: glutamate receptors and addiction}

Glutamate receptors are among the most well-studied edited mRNAs. Glutamate is the major excitatory neurotransmitter in the nervous system, and it mediates its fast synaptic action through the activation of three types of ionotropic glutamate receptors, including $\alpha$-amino-3-hydroxy-5-methyl-4-isoxazole propionic acid (AMPA) receptors (Choi, 1995; Dingledine et al., 1999). AMPA receptors (AMPARs) are tetrameric protein complexes comprised of GluA1-GluA4 subunits. Although all AMPARs are permeable to sodium and potassium (Song and Huganir, 2002), some AMPARs are also calcium permeable (CP). The synaptic incorporation of CP-AMPAR is highly regulated 
Table 1. Selected RNA modifications and their potential nervous system functions

\begin{tabular}{|c|c|c|}
\hline Modified RNA & Enzyme(s) & Potential nervous system function \\
\hline \multirow[t]{5}{*}{$\mathrm{m}^{6} \mathrm{~A}$} & Methyltransferase: & RNA splicing (Dominissini et al., 2012) \\
\hline & METTL3/METTL14/WTAP (Liu et al., 2014; Ping et al., 2014) & RNA stability (Wang et al., 2014b) \\
\hline & Demethylase: & Nuclear export (Dominissini et al., 2012) \\
\hline & FT0 (Jia et al., 2011) & Activity of dopaminergic neurons (Hess et al., 2013) \\
\hline & ALKBH5 (Zheng et al., 2013) & Hypothalamic response to nutrient status (Boender et al., 2012; Vujovic et al., 2013) \\
\hline \multirow[t]{6}{*}{$\mathrm{m}^{5} \mathrm{C}$} & Methyltransferase: & tRNA stability (Tuorto et al., 2012) \\
\hline & DNMT2 (Goll et al., 2006) & tRNA and ncRNA processing and cleavage (Schaefer et al., 2010; Hussain et al., 2013b; Blanco et al, 2014) \\
\hline & NSUN2 (Brzezicha et al., 2006; Frye and Watt, 2006) & Gene silencing (Hussain et al., 2013b) \\
\hline & NSUN4 (Metodiev et al.,. 2014) & Protein translation (Tuorto et al., 2012; Blanco et al., 2014) \\
\hline & Demethylase: & Stress response (Schaefer et al., 2010; Blanco et al., 2014) \\
\hline & unknown & Differentiation and development (Blanco et al., 2011; Tuorto et al., 2012; Hussain et al., 2013c) \\
\hline \multirow[t]{2}{*}{ Inosine } & ADARs (Nishikura, 2010) & RNA editing (Slotkin and Nishikura, 2013) \\
\hline & & Generation of nongenomically encoded proteins (Rueter et al., 1995; Wahlstedt et al., 2009) \\
\hline \multirow[t]{2}{*}{ circRNAs } & Unknown & MicroRNA sponge (Hansen et al., 2013; Memczak et al., 2013) \\
\hline & & Modulation of gene expression (Zhang et al., 2013) \\
\hline
\end{tabular}

and important for the enhanced synaptic strength associated with neuronal plasticity (Isaac et al., 2007; Liu and Zukin, 2007). CPAMPARs are altered by different pharmacological agents, demonstrate greater single-channel conductance, and demonstrate inward rectification due to voltage-dependent blockade by endogenous polyamines. Calcium-impermeable AMPARs are comprised of GluA2 subunits that have undergone RNA editing, which involves the enzymatic deamination of an adenosine residue in GluA2 pre-mRNA before splicing by the enzyme ADAR2 (Rueter et al., 1995; Melcher et al., 1996; Bass, 2002). ADAR2 specifically targets the glutamine $(\mathrm{Q})$ codon, deaminating an adenosine residue to an inosine that is read as guanosine $(\mathrm{CAG} \rightarrow$ CGG), by reverse transcriptase. Thus, ADAR2 converts the glutamine (Q) to arginine (R) at amino acid 607 changing a critical residue within the ion channel and thus generating AMPA receptors comprised of calcium-impermeable AMPARs with GluA2(R) subunits (Sommer et al., 1991; Geiger et al., 1995; Wright and Vissel, 2012). Although there is strong evidence that AMPARs lacking GluA2 contribute to normal brain function as well as disease, the functional significance of unedited GluA2(Q) containing AMPA receptors in the brain is unclear (Isaac et al., 2007; Wiltgen et al., 2010; Wright and Vissel, 2012). Recent studies demonstrate that unedited GluA2(Q) can play a role in both neurologic as well as psychiatric disorders (Morabito and Emeson, 2009). Unedited GluA2(Q) has been shown to regulate excitotoxic neuronal cell death in ischemia and neurodegenerative disease (Akbarian et al., 1995; Kawahara et al., 2004; Kwak and Weiss, 2006; Peng et al., 2006; Aizawa et al., 2010; Hideyama et al., 2010). Additionally, ADAR2 levels and GluA2 Q/R editing are decreased in the brains of patients with major depressive disorder and schizophrenia (Akbarian et al., 1995; Silberberg et al., 2012; Kubota-Sakashita et al., 2014).

Although a role for GluA2 Q/R site editing in excitotoxicity and neuronal death is becoming clear, its role in normal and aberrant behavioral phenotypes is largely unknown. Specifically, there are no studies that have yet examined a potential role for GluA2 editing in animal models of addiction. Recently, the SadriVakili group, together with Drs. Christopher Pierce and Heath Schmidt (University of Pennsylvania), has begun to elucidate the role of ADAR2-mediated GluA2 Q/R site editing in the nucleus accumbens (NAc) of rats following cocaine self-administration. It is now clear that AMPAR activation in the NAc promotes the reinstatement of cocaine-seeking behavior (Schmidt and Pierce,
2010). Although administration of an AMPAR agonist directly into the NAc reinstates cocaine seeking, intra-accumbal administration of an AMPAR antagonist decreases the reinstatement of drug seeking (Cornish and Kalivas, 2000; Di Ciano and Everitt, 2001; Backstrom and Hyytia, 2007; Conrad et al., 2008; Famous et al., 2008). Additionally, cocaine seeking is associated with increased synaptic expression of CP-AMPARs in the accumbens (Anderson et al., 2008; Conrad et al., 2008; Famous et al., 2008). Given that the majority of GluA2 subunits in the adult brain are edited GluA2(R), it has been speculated that cocaine-induced increases in NAc CP-AMPARs may reflect decreased expression of GluA2-containing AMPARs (Burnashev et al., 1992; Kawahara et al., 2003; Schmidt and Pierce, 2010; Pierce and Wolf, 2013). Alternatively, CP-AMPARs containing unedited GluA2(Q) subunits also could contribute to this process. The Sadri-Vakili laboratory is focused on addressing this issue by determining the effects of cocaine on ADAR2-mediated GluA2 Q/R site editing in a rat self-administration model.

\section{Circular RNAs (circRNAs)}

The final class of modified RNA we will discuss are the circular RNAs. circRNAs are a newly discovered class of stable, naturally occurring noncoding RNAs, with widespread expression in eukaryotic cells. Their extraordinary stability, due to their resistance to exonucleolitic RNA decay, offers the ability to efficiently sequester miRNAs or RNA-binding proteins and thereby affect their function. Although thousands of circular RNAs have been identified and many of these were shown to be the predominant transcript isoforms, little is known about their biogenesis, degradation, or function (Salzman et al., 2012, 2013; Jeck et al., 2013; Memczak et al., 2013; Wang et al., 2014a).

The Rajewsky laboratory has obtained evidence for numerous circRNAs with high expression in mammalian brain. Many of these circRNAs map to the exons of genes crucial for neuronal function. The best-characterized circRNA transcript CDR1as, antisense to cerebellar degeneration-related protein 1 (CDR1as/ ciRS-7), is densely bound by miRNA effector complex and harbors 63 conserved miR-7 binding sites (Hansen et al., 2013; Memczak et al., 2013). Gain-of-function experiments demonstrate that CDR1as acts as a natural miR-7 antagonist in neuronal tissues. Expression of CDR1as in zebrafish results in severe impairment of midbrain development, similar to miR-7 depletion, which indicates the ability of CDRlas to regulate miRNA-7 
levels (Memczak et al., 2013). Interestingly, miR-7 targets have been previously linked to Parkinson's disease etiology, and circCDR1as was shown to be strongly downregulated in the hippocampi of patients with Alzheimer's disease (Junn et al., 2009; Lukiw, 2013). This work suggests that maintenance of balance between CDR1as and miR-7 may be crucial for the prevention of neurodegenerative disease. The function of circRNAs is not necessarily limited to miRNA regulation. The biochemical heterogeneity and wide expression range of circRNAs suggest potential functions, such as delivery vehicles, RNA-binding protein sponges, assembly of RNA-binding protein factories, or as potential templates for translation (Hentze and Preiss, 2013; Memczak et al., 2013). Dr. Rybak-Wolf and her colleagues in the Rajewsky laboratory have investigated changes in circRNA expression during embryonic stem cell differentiation into neurons and have characterized some neuron-specific circRNAs with possible functions in the control of neuronal identity and development.

\section{Future exploration}

Research into RNA modifications is undergoing the beginnings of a renaissance thanks to improved tools and technologies for detecting these modifications. Table 1 summarizes the RNA modifications discussed in this mini-review and provides a brief description of their current known functions in the nervous system. These exciting discoveries will spur further investigations of the role of modified RNAs in a myriad of nervous system processes. Moving forward, it is evident that a few key obstacles must be overcome to achieve maximal progress in this area. These include the generation of improved affinity reagents to monitor specific modified RNAs, as well as improved assays that enable determination of specific RNA modifications at single base resolution. Additionally, a global survey of the RNA modifications in diverse neuronal and glial subtypes would be of great value in understanding the extent to which these modifications permeate the nervous system. It would also be important to identify and characterize the proteins that write, erase, or interact with these RNA modifications. If research in this field flourishes, an Epitranscriptome Catalog of RNA species and their modifications from a variety of key mammalian nervous system cell types or tissues will be of great use, as would computational approaches for predicting the presence of modifications in a given RNA. Certainly, additional mechanistic studies will be required for a more in-depth investigation of the mechanisms by which modified RNAs are generated and how these impact neurobiological and disease processes. Finally, genetic and pharmacological tools will need to be developed to enable temporal and cell-typespecific manipulation of RNA modifications and the proteins involved in their functions.

\section{References}

Abbasi-Moheb L, Mertel S, Gonsior M, Nouri-Vahid L, Kahrizi K, Cirak S, Wieczorek D, Motazacker MM, Esmaeeli-Nieh S, Cremer K, Weissmann R, Tzschach A, Garshasbi M, Abedini SS, Najmabadi H, Ropers HH, Sigrist SJ, Kuss AW (2012) Mutations in NSun2 cause autosomalrecessive intellectual disability. Am J Hum Genet 90:847-855. CrossRef Medline

Aizawa H, Sawada J, Hideyama T, Yamashita T, Katayama T, Hasebe N, Kimura T, Yahara O, Kwak S (2010) TDP-43 pathology in sporadic ALS occurs in motor neurons lacking the RNA editing enzyme ADAR2. Acta Neuropathol 120:75-84. CrossRef Medline

Akbarian S, Smith MA, Jones EG (1995) Editing for an AMPA receptor subunit RNA in prefrontal cortex and striatum in Alzheimer's disease, Huntington's disease and schizophrenia. Brain Res 699:297-304. CrossRef Medline
Alexandrov A, Chernyakov I, Gu W, Hiley SL, Hughes TR, Grayhack EJ, Phizicky EM (2006) Rapid tRNA decay can result from lack of nonessential modifications. Mol Cell 21:87-96. CrossRef Medline

Amort T, Soulière MF, Wille A, Jia XY, Fiegl H, Wörle H, Micura R, Lusser A (2013) Long non-coding RNAs as targets for cytosine methylation. RNA Biol 10:1003-1008. CrossRef Medline

Anderson SM, Famous KR, Sadri-Vakili G, Kumaresan V, Schmidt HD, Bass CE, Terwilliger EF, Cha JH, Pierce RC (2008) CaMKII: a biochemical bridge linking accumbens dopamine and glutamate systems in cocaine seeking. Nat Neurosci 11:344-353. CrossRef Medline

Backstrom P, Hyytia P (2007) Involvement of AMPA/kainate, NMDA, and $\mathrm{mGlu} 5$ receptors in the nucleus accumbens core in cue-induced reinstatement of cocaine seeking in rats. Psychopharmacology (Berl) 192:571-580. CrossRef Medline

Bahn JH, Lee JH, Li G, Greer C, Peng G, Xiao X (2012) Accurate identification of A-to-I RNA editing in human by transcriptome sequencing. Genome Res 22:142-150. CrossRef Medline

Bass BL (2002) RNA editing by adenosine deaminases that act on RNA. Annu Rev Biochem 71:817-846. CrossRef Medline

Behm-Ansmant I, Helm M, Motorin Y (2011) Use of specific chemical reagents for detection of modified nucleotides in RNA. J Nucleic Acids 2011:408053. CrossRef Medline

Blanco S, Kurowski A, Nichols J, Watt FM, Benitah SA, Frye M (2011) The RNA-methyltransferase Misu (NSun2) poises epidermal stem cells to differentiate. PLoS Genet 7:e1002403. CrossRef Medline

Blanco S, Dietmann S, Flores JV, Hussain S, Kutter C, Humphreys P, Lukk M, Lombard P, Treps L, Popis M, Kellner S, Hölter SM, Garrett L, Wurst W, Becker L, Klopstock T, Fuchs H, Gailus-Durner V, Hrabĕ de Angelis M, Káradóttir RT, et al. (2014) Aberrant methylation of tRNAs links cellular stress to neuro-developmental disorders. EMBO J 33:2020-2039. CrossRef Medline

Boender AJ, van Rozen AJ, Adan RA (2012) Nutritional state affects the expression of the obesity-associated genes Etv5, Faim2, Fto, and Negr1. Obesity (Silver Spring) 20:2420-2425. CrossRef Medline

Brusa R, Zimmermann F, Koh DS, Feldmeyer D, Gass P, Seeburg PH, Sprengel R (1995) Early-onset epilepsy and postnatal lethality associated with an editing-deficient GluR-B allele in mice. Science 270:1677-1680. CrossRef Medline

Brzezicha B, Schmidt M, Makalowska I, Jarmolowski A, Pienkowska J, Szweykowska-Kulinska Z (2006) Identification of human tRNA:m5C methyltransferase catalysing intron-dependent $\mathrm{m} 5 \mathrm{C}$ formation in the first position of the anticodon of the pre-tRNA Leu (CAA). Nucleic Acids Res 34:6034-6043. CrossRef Medline

Burnashev N, Monyer H, Seeburg PH, Sakmann B (1992) Divalent ion permeability of AMPA receptor channels is dominated by the edited form of a single subunit. Neuron 8:189-198. CrossRef Medline

Cantara WA, Crain PF, Rozenski J, McCloskey JA, Harris KA, Zhang X, Vendeix FA, Fabris D, Agris PF (2011) The RNA Modification Database, RNAMDB: 2011 update. Nucleic Acids Res 39:D195-D201. CrossRef Medline

Chan CT, Pang YL, Deng W, Babu IR, Dyavaiah M, Begley TJ, Dedon PC (2012) Reprogramming of tRNA modifications controls the oxidative stress response by codon-biased translation of proteins. Nat Commun 3:937. CrossRef Medline

Chen CX, Cho DS, Wang Q, Lai F, Carter KC, Nishikura K (2000) A third member of the RNA-specific adenosine deaminase gene family, ADAR3, contains both single- and double-stranded RNA binding domains. RNA 6:755-767. CrossRef Medline

Chernyakov I, Whipple JM, Kotelawala L, Grayhack EJ, Phizicky EM (2008) Degradation of several hypomodified mature tRNA species in Saccharomyces cerevisiae is mediated by Met 22 and the $5^{\prime}-3^{\prime}$ exonucleases Rat 1 and Xrn1. Genes Dev 22:1369-1380. CrossRef Medline

Choi DW (1995) Calcium: still center-stage in hypoxic-ischemic neuronal death. Trends Neurosci 18:58-60. CrossRef Medline

Choudhry Z, Sengupta SM, Grizenko N, Thakur GA, Fortier ME, Schmitz N, Joober R (2013) Association between obesity-related gene FTO and ADHD. Obesity (Silver Spring) 21:E738-E744. CrossRef Medline

Chow CS, Lamichhane TN, Mahto SK (2007) Expanding the nucleotide repertoire of the ribosome with post-transcriptional modifications. ACS Chem Biol 2:610-619. CrossRef Medline

Conrad KL, Tseng KY, Uejima JL, Reimers JM, Heng LJ, Shaham Y, Marinelli M, Wolf ME (2008) Formation of accumbens GluR2-lacking AMPA re- 
ceptors mediates incubation of cocaine craving. Nature 454:118-121. CrossRef Medline

Cornish JL, Kalivas PW (2000) Glutamate transmission in the nucleus accumbens mediates relapse in cocaine addiction. J Neurosci 20:RC89. Medline

Danecek P, Nellåker C, McIntyre RE, Buendia-Buendia JE, Bumpstead S, Ponting CP, Flint J, Durbin R, Keane TM, Adams DJ (2012) High levels of RNA-editing site conservation amongst 15 laboratory mouse strains. Genome Biol 13:26. CrossRef Medline

De Felice C, Signorini C, Leoncini S, Pecorelli A, Durand T, Valacchi G, Ciccoli L, Hayek J (2012) The role of oxidative stress in Rett syndrome: an overview. Ann N Y Acad Sci 1259:121-135. CrossRef Medline

Di Ciano P, Everitt BJ (2001) Dissociable effects of antagonism of NMDA and AMPA/KA receptors in the nucleus accumbens core and shell on cocaine-seeking behavior. Neuropsychopharmacology 25:341-360. CrossRef Medline

Dingledine R, Borges K, Bowie D, Traynelis SF (1999) The glutamate receptor ion channels. Pharmacol Rev 51:7-61. Medline

Dominissini D, Moshitch-Moshkovitz S, Schwartz S, Salmon-Divon M, Ungar L, Osenberg S, Cesarkas K, Jacob-Hirsch J, Amariglio N, Kupiec M, Sorek R, Rechavi G (2012) Topology of the human and mouse m6A RNA methylomes revealed by m6A-seq. Nature 485:201-206. CrossRef Medline

Edelheit S, Schwartz S, Mumbach MR, Wurtzel O, Sorek R (2013) Transcriptome-wide mapping of 5-methylcytidine RNA modifications in bacteria, archaea, and yeast reveals $\mathrm{m} 5 \mathrm{C}$ within archaeal mRNAs. PLoS Genet 9:e1003602. CrossRef Medline

Emara MM, Ivanov P, Hickman T, Dawra N, Tisdale S, Kedersha N, Hu GF, Anderson P (2010) Angiogenin-induced tRNA-derived stress-induced RNAs promote stress-induced stress granule assembly. J Biol Chem 285: 10959-10968. CrossRef Medline

Fahiminiya S, Almuriekhi M, Nawaz Z, Staffa A, Lepage P, Ali R, Hashim L, Schwartzentruber J, Abu KhadijaK, Zaineddin S, Gamal H, Majewski J, Ben-Omran T (2014) Whole exome sequencing unravels diseasecausing genes in consanguineous families in Qatar. Clin Genet 86:134141. CrossRef Medline

Famous KR, Kumaresan V, Sadri-Vakili G, Schmidt HD, Mierke DF, Cha JH, Pierce RC (2008) Phosphorylation-dependent trafficking of GluR2containing AMPA receptors in the nucleus accumbens plays a critical role in the reinstatement of cocaine seeking. J Neurosci 28:11061-11070. CrossRef Medline

Frye M, Watt FM (2006) The RNA methyltransferase Misu (NSun2) mediates Myc-induced proliferation and is upregulated in tumors. Curr Biol 16:971-981. CrossRef Medline

Frye M, Dragoni I, Chin SF, Spiteri I, Kurowski A, Provenzano E, Green A, Ellis IO, Grimmer D, Teschendorff A, Zouboulis CC, Caldas C, Watt FM (2010) Genomic gain of 5p15 leads to over-expression of Misu (NSUN2) in breast cancer. Cancer Lett 289:71-80. CrossRef Medline

Fu H, Feng J, Liu Q, Sun F, Tie Y, Zhu J, Xing R, Sun Z, Zheng X (2009) Stress induces tRNA cleavage by angiogenin in mammalian cells. FEBS Lett 583:437-442. CrossRef Medline

Garcia-Closas M, Couch FJ, Lindstrom S, Michailidou K, Schmidt MK, Brook MN, Orr N, Rhie SK, Riboli E, Feigelson HS, Le Marchand L, Buring JE, Eccles D, Miron P, Fasching PA, Brauch H, Chang-Claude J, Carpenter J, Godwin AK, Nevanlinna H, et al. (2013) Genome-wide association studies identify four ER negative-specific breast cancer risk loci. Nat Genet 45:392. CrossRef Medline

Gebetsberger J, Zywicki M, Künzi A, Polacek N (2012) tRNA-derived fragments target the ribosome and function as regulatory non-coding RNA in Haloferax volcanii. Archaea 2012:260909. CrossRef Medline

Geiger JR, Melcher T, Koh DS, Sakmann B, Seeburg PH, Jonas P, Monyer H (1995) Relative abundance of subunit mRNAs determines gating and $\mathrm{Ca}^{2+}$ permeability of AMPA receptors in principal neurons and interneurons in rat CNS. Neuron 15:193-204. CrossRef Medline

Gold M, Hurwitz J, Anders M (1963) The enzymatic methylation of RNA and DNA: II. On the species specificity of the methylation enzymes. Proc Natl Acad Sci U S A 50:164-169. CrossRef Medline

Goll MG, Kirpekar F, Maggert KA, Yoder JA, Hsieh CL, Zhang X, Golic KG, Jacobsen SE, Bestor TH (2006) Methylation of tRNAAsp by the DNA methyltransferase homolog Dnmt2. Science 311:395-398. CrossRef Medline
Hansen TB, Jensen TI, Clausen BH, Bramsen JB, Finsen B, Damgaard CK, Kjems J (2013) Natural RNA circles function as efficient microRNA sponges. Nature 495:384-388. CrossRef Medline

Hentze MW, Preiss T (2013) Circular RNAs: splicing's enigma variations. EMBO J 32:923-925. CrossRef Medline

Hess ME, Hess S, Meyer KD, Verhagen LA, Koch L, Brönneke HS, Dietrich MO, Jordan SD, Saletore Y, Elemento O, Belgardt BF, Franz T, Horvath TL, Rüther U, Jaffrey SR, Kloppenburg P, Brüning JC (2013) The fat mass and obesity associated gene (Fto) regulates activity of the dopaminergic midbrain circuitry. Nat Neurosci 16:1042-1048. CrossRef Medline

Hideyama T, Yamashita T, Suzuki T, Tsuji S, Higuchi M, Seeburg PH, Takahashi R, Misawa H, Kwak S (2010) Induced loss of ADAR2 engenders slow death of motor neurons from Q/R site-unedited GluR2. J Neurosci 30:11917-11925. CrossRef Medline

Ho AJ, Stein JL, Hua X, Lee S, Hibar DP, Leow AD, Dinov ID, Toga AW, Saykin AJ, Shen L, Foroud T, Pankratz N, Huentelman MJ, Craig DW, Gerber JD, Allen AN, Corneveaux JJ, Stephan DA, DeCarli CS, DeChairo BM, et al. (2010) A commonly carried allele of the obesity-related FTO gene is associated with reduced brain volume in the healthy elderly. Proc Natl Acad Sci U S A 107:8404-8409. CrossRef Medline

Hussain S, Benavente SB, Nascimento E, Dragoni I, Kurowski A, Gillich A, Humphreys P, Frye M (2009) The nucleolar RNA methyltransferase Misu (NSun2) is required for mitotic spindle stability. J Cell Biol 186:27-40. CrossRef Medline

Hussain S, Aleksic J, Blanco S, Dietmann S, Frye M (2013a) Characterizing 5-methylcytosine in the mammalian epitranscriptome. Genome Biol 14: 215. CrossRef Medline

Hussain S, Sajini AA, Blanco S, Dietmann S, Lombard P, Sugimoto Y, Paramor M, Gleeson JG, Odom DT, Ule J, Frye M (2013b) NSun2mediated cytosine- 5 methylation of vault noncoding RNA determines its processing into regulatory small RNAs. Cell Rep 4:255-261. CrossRef Medline

Hussain S, Tuorto F, Menon S, Blanco S, Cox C, Flores JV, Watt S, Kudo NR, Lyko F, Frye M (2013c) The mouse cytosine-5 RNA methyltransferase NSun2 is a component of the chromatoid body and required for testis differentiation. Mol Cell Biol 33:1561-1570. CrossRef Medline

Iles MM, Law MH, Stacey SN, Han J, Fang S, Pfeiffer R, Harland M, Macgregor S, Taylor JC, Aben KK, Akslen LA, Avril MF, Azizi E, Bakker B, Benediktsdottir KR, Bergman W, Scarrà GB, Brown KM, Calista D, Chaudru V, et al. (2013) A variant in FTO shows association with melanoma risk not due to BMI. Nat Genet 45:428-432. CrossRef Medline

Im HI, Kenny PJ (2012) MicroRNAs in neuronal function and dysfunction. Trends Neurosci 35:325-334. CrossRef Medline

Isaac JT, Ashby MC, McBain CJ (2007) The role of the GluR2 subunit in AMPA receptor function and synaptic plasticity. Neuron 54:859-871. CrossRef Medline

Ivanov P, Emara MM, Villen J, Gygi SP, Anderson P (2011) Angiogenininduced tRNA fragments inhibit translation initiation. Mol Cell 43:613623. CrossRef Medline

Jeck WR, Sorrentino JA, Wang K, Slevin MK, Burd CE, Liu J, Marzluff WF, Sharpless NE (2013) Circular RNAs are abundant, conserved, and associated with ALU repeats. RNA 19:141-157. CrossRef Medline

Jia G, Fu Y, Zhao X, Dai Q, Zheng G, Yang Y, Yi C, Lindahl T, Pan T, Yang YG, $\mathrm{He} \mathrm{C}$ (2011) N6-methyladenosine in nuclear RNA is a major substrate of the obesity-associated FTO. Nat Chem Biol 7:885-887. CrossRef Medline

Junn E, Lee KW, Jeong BS, Chan TW, Im JY, Mouradian MM (2009) Repression of alpha-synuclein expression and toxicity by microRNA-7. Proc Natl Acad Sci U S A 106:13052-13057. CrossRef Medline

Karaca E, Weitzer S, Pehlivan D, Shiraishi H, Gogakos T, Hanada T, Jhangiani SN, Wiszniewski W, Withers M, Campbell IM, Erdin S, Isikay S, Franco LM, Gonzaga-Jauregui C, Gambin T, Gelowani V, Hunter JV, Yesil G, Koparir E, Yilmaz S, et al. (2014) Human CLP1 mutations alter tRNA biogenesis, affecting both peripheral and central nervous system function. Cell 157:636-650. CrossRef Medline

Kawahara Y, Ito K, Sun H, Kanazawa I, Kwak S (2003) Low editing efficiency of GluR2 mRNA is associated with a low relative abundance of ADAR2 mRNA in white matter of normal human brain. Eur J Neurosci 18:23-33. CrossRef Medline

Kawahara Y, Ito K, Sun H, Aizawa H, Kanazawa I, Kwak S (2004) Glutamate receptors: RNA editing and death of motor neurons. Nature 427:801. CrossRef Medline 
Kawahara Y, Zinshteyn B, Sethupathy P, Iizasa H, Hatzigeorgiou AG, Nishikura K (2007) Redirection of silencing targets by adenosine-to-inosine editing of miRNAs. Science 315:1137-1140. CrossRef Medline

Keller L, Xu W, Wang HX, Winblad B, Fratiglioni L, Graff C (2011) The obesity related gene, FTO, interacts with APOE, and is associated with Alzheimer's disease risk: a prospective cohort study. J Alzheimers Dis 23:461-469. CrossRef Medline

Khan MA, Rafiq MA, Noor A, Hussain S, Flores JV, Rupp V, Vincent AK, Malli R, Ali G, Khan FS, Ishak GE, Doherty D, Weksberg R, Ayub M, Windpassinger C, Ibrahim S, Frye M, Ansar M, Vincent JB (2012) Mutation in NSUN2, which encodes an RNA methyltransferase, causes autosomal-recessive intellectual disability. Am J Hum Genet 90:856-863. CrossRef Medline

Khoddami V, Cairns BR (2013) Identification of direct targets and modified bases of RNA cytosine methyltransferases. Nat Biotechnol 31:458-464. CrossRef Medline

Kubota-Sakashita M, Iwamoto K, Bundo M, Kato T (2014) A role of ADAR2 and RNA editing of glutamate receptors in mood disorders and schizophrenia. Mol Brain 7:5. CrossRef Medline

Kullolli M, Knouf E, Arampatzidou M, Tewari M, Pitteri SJ (2014) Intact microRNA analysis using high resolution mass spectrometry. J Am Soc Mass Spectrom 25:80-87. CrossRef Medline

Kwak S, Weiss JH (2006) Calcium-permeable AMPA channels in neurodegenerative disease and ischemia. Curr Opin Neurobiol 16:281-287. CrossRef Medline

Li JB, Church GM (2013) Deciphering the functions and regulation of brain-enriched A-to-I RNA editing. Nat Neurosci 16:1518-1522. CrossRef Medline

Li JB, Levanon EY, Yoon JK, Aach J, Xie B, Leproust E, Zhang K, Gao Y, Church GM (2009) Genome-wide identification of human RNA editing sites by parallel DNA capturing and sequencing. Science 324:1210-1213. CrossRef Medline

Li S, Mason CE (2014) The pivotal regulatory landscape of RNA modifications. Annu Rev Genomics Hum Genet 15:127-150. CrossRef Medline

Lintas C, Sacco R, Persico AM (2012) Genome-wide expression studies in autism spectrum disorder, Rett syndrome, and Down syndrome. Neurobiol Dis 45:57-68. CrossRef Medline

Liu J, Yue Y, Han D, Wang X, Fu Y, Zhang L, Jia G, Yu M, Lu Z, Deng X, Dai Q, Chen W, He C (2014) A METTL3-METTL14 complex mediates mammalian nuclear RNA N6-adenosine methylation. Nat Chem Biol 10:93-95. CrossRef Medline

Liu SJ, Zukin RS (2007) $\mathrm{Ca}^{2+}$-permeable AMPA receptors in synaptic plasticity and neuronal death. Trends Neurosci 30:126-134. CrossRef Medline

Lukiw WJ (2013) Circular RNA (circRNA) in Alzheimer's disease (AD). Front Genet 4:307. CrossRef Medline

Martinez FJ, Lee JH, Lee JE, Blanco S, Nickerson E, Gabriel S, Frye M, AlGazali L, Gleeson JG (2012) Whole exome sequencing identifies a splicing mutation in NSUN2 as a cause of a Dubowitz-like syndrome. J Med Genet 49:380-385. CrossRef Medline

Matera AG, Terns RM, Terns MP (2007) Non-coding RNAs: lessons from the small nuclear and small nucleolar RNAs. Nat Rev Mol Cell Biol 8:209220. CrossRef Medline

Melcher T, Maas S, Herb A, Sprengel R, Seeburg PH, Higuchi M (1996) A mammalian RNA editing enzyme. Nature 379:460-464. CrossRef Medline

Melka MG, Gillis J, Bernard M, Abrahamowicz M, Chakravarty MM, Leonard GT, Perron M, Richer L, Veillette S, Banaschewski T, Barker GJ, Büchel C, Conrod P, Flor H, Heinz A, Garavan H, Brühl R, Mann K, Artiges E, Lourdusamy A, et al. (2013) FTO, obesity and the adolescent brain. Hum Mol Genet 22:1050-1058. CrossRef Medline

Memczak S, Jens M, Elefsinioti A, Torti F, Krueger J, Rybak A, Maier L, Mackowiak SD, Gregersen LH, Munschauer M, Loewer A, Ziebold U, Landthaler M, Kocks C, le Noble F, Rajewsky N (2013) Circular RNAs are a large class of animal RNAs with regulatory potency. Nature 495:333338. CrossRef Medline

Metodiev MD, Spåhr H, Loguercio Polosa P, Meharg C, Becker C, Altmueller J, Habermann B, Larsson NG, Ruzzenente B (2014) NSUN4 is a dual function mitochondrial protein required for both methylation of $12 \mathrm{~S}$ rRNA and coordination of mitoribosomal assembly. PLoS Genet 10: e1004110. CrossRef Medline
Meyer KD, Jaffrey SR (2014) The dynamic epitranscriptome: N6methyladenosine and gene expression control. Nat Rev Mol Cell Biol 15:313-326. CrossRef Medline

Meyer KD, Saletore Y, Zumbo P, Elemento O, Mason CE, Jaffrey SR (2012) Comprehensive analysis of mRNA methylation reveals enrichment in $3^{\prime}$ UTRs and near stop codons. Cell 149:1635-1646. CrossRef Medline

Morabito MV, Emeson RB (2009) RNA editing as a therapeutic target for CNS disorders. Neuropsychopharmacology 34:246. CrossRef Medline

Motorin Y, Lyko F, Helm M (2010) 5-Methylcytosine in RNA: detection, enzymatic formation and biological functions. Nucleic Acids Res 38: 1415-1430. CrossRef Medline

Ng SY, Lin L, Soh BS, Stanton LW (2013) Long noncoding RNAs in development and disease of the central nervous system. Trends Genet 29:461468. CrossRef Medline

Nishikura K (2010) Functions and regulation of RNA editing by ADAR deaminases. Annu Rev Biochem 79:321-349. CrossRef Medline

Peng PL, Zhong X, Tu W, Soundarapandian MM, Molner P, Zhu D, Lau L, Liu S, Liu F, Lu Y (2006) ADAR2-dependent RNA editing of AMPA receptor subunit GluR2 determines vulnerability of neurons in forebrain ischemia. Neuron 49:719-733. CrossRef Medline

Peng Z, Cheng Y, Tan BC, Kang L, Tian Z, Zhu Y, Zhang W, Liang Y, Hu X, Tan X, Guo J, Dong Z, Liang Y, Bao L, Wang J (2012) Comprehensive analysis of RNA-Seq data reveals extensive RNA editing in a human transcriptome. Nat Biotechnol 30:253-260. CrossRef Medline

Petri R, Malmevik J, Fasching L, Åkerblom M, Jakobsson J (2014) miRNAs in brain development. Exp Cell Res 321:84-89. CrossRef Medline

Pierce RC, Wolf ME (2013) Psychostimulant-induced neuroadaptations in nucleus accumbens AMPA receptor transmission. Cold Spring Harb Perspect Med 3:a012021. CrossRef Medline

Ping XL, Sun BF, Wang L, Xiao W, Yang X, Wang WJ, Adhikari S, Shi Y, Lv Y, Chen YS, Zhao X, Li A, Yang Y, Dahal U, Lou XM, Liu X, Huang J, Yuan WP, Zhu XF, Cheng T, et al. (2014) Mammalian WTAP is a regulatory subunit of the RNA N6-methyladenosine methyltransferase. Cell Res 24: 177-189. CrossRef Medline

Quinn R, Basanta-Sanchez M, Rose RE, Fabris D (2013) Direct infusion analysis of nucleotide mixtures of very similar or identical elemental composition. J Mass Spectrom 48:703-712. CrossRef Medline

Qureshi IA, Mehler MF (2012) Emerging roles of non-coding RNAs in brain evolution, development, plasticity and disease. Nat Rev Neurosci 13:528-541. CrossRef Medline

Rai K, Chidester S, Zavala CV, Manos EJ, James SR, Karpf AR, Jones DA, Cairns BR (2007) Dnmt2 functions in the cytoplasm to promote liver, brain, and retina development in zebrafish. Genes Dev 21:261-266. CrossRef Medline

Ramaswami G, Li JB (2014) RADAR: a rigorously annotated database of A-to-I RNA editing. Nucleic Acids Res 42:D109-D113. CrossRef Medline

Ramaswami G, Lin W, Piskol R, Tan MH, Davis C, Li JB (2012) Accurate identification of human Alu and non-Alu RNA editing sites. Nat Methods 9:579-581. CrossRef Medline

Ramaswami G, Zhang R, Piskol R, Keegan LP, Deng P, O'Connell MA, Li JB (2013) Identifying RNA editing sites using RNA sequencing data alone. Nat Methods 10:128-132. CrossRef Medline

Reitz C, Tosto G, Mayeux R, Luchsinger JA (2012) Genetic variants in the Fat and Obesity Associated (FTO) gene and risk of Alzheimer's disease. PLoS One 7:e50354. CrossRef Medline

Roberts TC, Morris KV, Wood MJ (2014) The role of long non-coding RNAs in neurodevelopment, brain function and neurological disease. Philos Trans R Soc Lond B Biol Sci 369:pii.20130507. CrossRef Medline

Rosenthal JJ, Seeburg PH (2012) A-to-I RNA editing: effects on proteins key to neural excitability. Neuron 74:432-439. CrossRef Medline

Rueter SM, Burns CM, Coode SA, Mookherjee P, Emeson RB (1995) Glutamate receptor RNA editing in vitro by enzymatic conversion of adenosine to inosine. Science 267:1491-1494. CrossRef Medline

Rueter SM, Dawson TR, Emeson RB (1999) Regulation of alternative splicing by RNA editing. Nature 399:75-80. CrossRef Medline

Russell SP, Limbach PA (2013) Evaluating the reproducibility of quantifying modified nucleosides from ribonucleic acids by LC-UV-MS. J Chromatogr B Analyt Technol Biomed Life Sci 924:74-82. CrossRef Medline

Sakita-Suto S, Kanda A, Suzuki F, Sato S, Takata T, Tatsuka M (2007) Aurora-B regulates RNA methyltransferase NSUN2. Mol Biol Cell 18: 1107-1117. CrossRef Medline 
Saletore Y, Meyer K, Korlach J, Vilfan ID, Jaffrey S, Mason CE (2012) The birth of the Epitranscriptome: deciphering the function of RNA modifications. Genome Biol 13:175. CrossRef Medline

Salzman J, Gawad C, Wang PL, Lacayo N, Brown PO (2012) Circular RNAs are the predominant transcript isoform from hundreds of human genes in diverse cell types. PLoS One 7:e30733. CrossRef Medline

Salzman J, Chen RE, Olsen MN, Wang PL, Brown PO (2013) Cell-type specific features of circular RNA expression. PLoS Genet 9:e1003777. CrossRef Medline

Satterlee JS, Barbee S, Jin P, Krichevsky A, Salama S, Schratt G, Wu DY (2007) Noncoding RNAs in the brain. J Neurosci 27:11856-11859. CrossRef Medline

Schaefer M, Pollex T, Hanna K, Lyko F (2009) RNA cytosine methylation analysis by bisulfite sequencing. Nucleic Acids Res 37:e12. CrossRef Medline

Schaefer M, Pollex T, Hanna K, Tuorto F, Meusburger M, Helm M, Lyko F (2010) RNA methylation by Dnmt2 protects transfer RNAs against stress-induced cleavage. Genes Dev 24:1590-1595. CrossRef Medline

Schaffer AE, Eggens VR, Caglayan AO, Reuter MS, Scott E, Coufal NG, Silhavy JL, Xue Y, Kayserili H, Yasuno K, Rosti RO, Abdellateef M, Caglar C, Kasher PR, Cazemier JL, Weterman MA, Cantagrel V, Cai N, Zweier C, Altunoglu U, et al. (2014) CLP1 founder mutation links tRNA splicing and maturation to cerebellar development and neurodegeneration. Cell 157:651-663. CrossRef Medline

Schmidt HD, Pierce RC (2010) Cocaine-induced neuroadaptations in glutamate transmission: potential therapeutic targets for craving and addiction. Ann N Y Acad Sci 1187:35-75. CrossRef Medline

Schwartz S, Agarwala SD, Mumbach MR, Jovanovic M, Mertins P, Shishkin A, Tabach Y, Mikkelsen TS, Satija R, Ruvkun G, Carr SA, Lander ES, Fink GR, Regev A (2013) High-resolution mapping reveals a conserved, widespread, dynamic mRNA methylation program in yeast meiosis. Cell 155:1409-1421. CrossRef Medline

Silberberg G, Lundin D, Navon R, Öhman M (2012) Deregulation of the A-to-I RNA editing mechanism in psychiatric disorders. Hum Mol Genet 21:311-321. CrossRef Medline

Slotkin W, Nishikura K (2013) Adenosine-to-inosine RNA editing and human disease. Genome Med 5:105. CrossRef Medline

Sobala A, Hutvagner G (2013) Small RNAs derived from the 5' end of tRNA can inhibit protein translation in human cells. RNA Biol 10:553-563. CrossRef Medline

Sommer B, Köhler M, Sprengel R, Seeburg PH (1991) RNA editing in brain controls a determinant of ion flow in glutamate-gated channels. Cell 67: 11-19. CrossRef Medline

Song I, Huganir RL (2002) Regulation of AMPA receptors during synaptic plasticity. Trends Neurosci 25:578-588. CrossRef Medline

Spriggs KA, Bushell M, Willis AE (2010) Translational regulation of gene expression during conditions of cell stress. Mol Cell 40:228-237. CrossRef Medline

Squires JE, Patel HR, Nousch M, Sibbritt T, Humphreys DT, Parker BJ, Suter CM, Preiss T (2012) Widespread occurrence of 5-methylcytosine in human coding and non-coding RNA. Nucleic Acids Res 40:5023-5033. CrossRef Medline

Storz G (2002) An expanding universe of noncoding RNAs. Science 296: 1260-1263. CrossRef Medline

Su D, Chan CT, Gu C, Lim KS, Chionh YH, McBee ME, Russell BS, Babu IR, Begley TJ, Dedon PC (2014) Quantitative analysis of ribonucleoside modifications in tRNA by HPLC-coupled mass spectrometry. Nat Protoc 9:828-841. CrossRef Medline

Tariq A, Jantsch MF (2012) Transcript diversification in the nervous system: A to I RNA editing in CNS function and disease development. Front Neurosci 6:99. CrossRef Medline
Thompson DM, Lu C, Green PJ, Parker R (2008) tRNA cleavage is a conserved response to oxidative stress in eukaryotes. RNA 14:2095-2103. CrossRef Medline

Tung YC, Yeo GS (2011) From GWAS to biology: lessons from FTO. Ann N Y Acad Sci 1220:162-171. CrossRef Medline

Tuorto F, Liebers R, Musch T, Schaefer M, Hofmann S, Kellner S, Frye M, Helm M, Stoecklin G, Lyko F (2012) RNA cytosine methylation by Dnmt2 and NSun2 promotes tRNA stability and protein synthesis. Nat Struct Mol Biol 19:900-905. CrossRef Medline

van de Leemput J, Boles NC, Kiehl TR, Corneo B, Lederman P, Menon V, Lee C, Martinez RA, Levi BP, Thompson CL, Yao S, Kaykas A, Temple S, Fasano CA (2014) CORTECON: a temporal transcriptome analysis of in vitro human cerebral cortex development from human embryonic stem cells. Neuron 83:51-68. CrossRef Medline

Vujovic P, Stamenkovic S, Jasnic N, Lakic I, Djurasevic SF, Cvijic G, Djordjevic J (2013) Fasting induced cytoplasmic Fto expression in some neurons of rat hypothalamus. PLoS One 8:e63694. CrossRef Medline

Wahlstedt H, Daniel C, Ensterö M, Ohman M (2009) Large-scale mRNA sequencing determines global regulation of RNA editing during brain development. Genome Res 19:978-986. CrossRef Medline

Wang PL, Bao Y, Yee MC, Barrett SP, Hogan GJ, Olsen MN, Dinneny JR, Brown PO, Salzman J (2014a) Circular RNA is expressed across the eukaryotic tree of life. PLoS One 9:e90859. CrossRef Medline

Wang X, Lu Z, Gomez A, Hon GC, Yue Y, Han D, Fu Y, Parisien M, Dai Q, Jia G, Ren B, Pan T, He C (2014b) N6-methyladenosine-dependent regulation of messenger RNA stability. Nature 505:117-120. CrossRef Medline

Wang Y, Li Y, Toth JI, Petroski MD, Zhang Z, Zhao JC (2014c) N6methyladenosine modification destabilizes developmental regulators in embryonic stem cells. Nat Cell Biol 16:191-198. CrossRef Medline

Wiltgen BJ, Royle GA, Gray EE, Abdipranoto A, Thangthaeng N, Jacobs N, Saab F, Tonegawa S, Heinemann SF, O’Dell TJ, Fanselow MS, Vissel B (2010) A role for calcium-permeable AMPA receptors in synaptic plasticity and learning. PLoS One 5:pii.e.12818. CrossRef Medline

Wright A, Vissel B (2012) The essential role of AMPA receptor GluR2 subunit RNA editing in the normal and diseased brain. Front Mol Neurosci 5:34. CrossRef Medline

Yamasaki S, Ivanov P, Hu GF, Anderson P (2009) Angiogenin cleaves tRNA and promotes stress-induced translational repression. J Cell Biol 185:3542. CrossRef Medline

Yan M, Wang Y, Hu Y, Feng Y, Dai C, Wu J, Wu D, Zhang F, Zhai Q (2013) A high-throughput quantitative approach reveals more small RNA modifications in mouse liver and their correlation with diabetes. Anal Chem 85:12173-12181. CrossRef Medline

Yu B, Chen X (2010) Analysis of miRNA modifications. Methods Mol Biol 592:137-148. CrossRef Medline

Zhang R, Li X, Ramaswami G, Smith KS, Turecki G, Montgomery SB, Li JB (2014) Quantifying RNA allelic ratios by microfluidic multiplex PCR and sequencing. Nat Methods 11:51-54. CrossRef Medline

Zhang X, Liu Z, Yi J, Tang H, Xing J, Yu M, Tong T, Shang Y, Gorospe M, Wang W (2012) The tRNA methyltransferase NSun2 stabilizes p16INK(4) mRNA by methylating the $3^{\prime}$-untranslated region of p16. Nat Commun 3:712. CrossRef Medline

Zhang Y, Zhang XO, Chen T, Xiang JF, Yin QF, Xing YH, Zhu S, Yang L, Chen LL (2013) Circular intronic long noncoding RNAs. Mol Cell 51:792806. CrossRef Medline

Zheng G, Dahl JA, Niu Y, Fedorcsak P, Huang CM, Li CJ, Vågbø CB, Shi Y, Wang WL, Song SH, Lu Z, Bosmans RP, Dai Q, Hao YJ, Yang X, Zhao WM, Tong WM, Wang XJ, Bogdan F, Furu K, et al. (2013) ALKBH5 is a mammalian RNA demethylase that impacts RNA metabolism and mouse fertility. Mol Cell 49:18-29. CrossRef Medline 